\title{
Reflections on the Beginnings of an Educational Revolution (?)
}

\author{
Arthur Tatnall $^{1}$ and Bill Davey ${ }^{2}$ \\ ${ }^{1}$ Victoria University, Australia \\ ${ }^{2}$ RMIT University, Australia \\ Arthur.Tatnall@vu.edu.au, Bill.Davey@RMIT.edu.au
}

\begin{abstract}
If you have read through all the chapters in this book you will have encountered reflections and stories from around the world from the 1970s up to the mid-1990s. An analysis of all of these stories, set in very different countries and systems, shows that the revolution can be said to have begun in the late1970s and early-1980s. The book also describes some significant events into the 1990s and beyond, but does not go much further into this area: that will have to be for another book! Chapters relate to the introduction of computers into schools in Canada, Norway, The Netherlands, Australia, Spain, Ireland, Israel, New Zealand, USA, Finland, UK, Chile, Poland and South Africa.

In this chapter we will attempt to draw together themes common to the stories from the previous chapters. Many chapters have dealt with more than one of these themes even though many countries and systems are covered. We will also consider the aspirations and motivations of these pioneering efforts to introduce computers into the classroom and contemplate outcomes at the end of this period.
\end{abstract}

Keywords: National policies, personal reflections, teachers, students, teacher education, curriculum.

\section{$1 \quad$ National Policies, Issues and Developments}

Many chapters of this book have dealt primarily with how the introduction of computers in education happened in the country of the author, and described national policies and issues that arose in this early period. Some chapters were written from a very personal perspective, others just described what happened. The contributions related to: Norway (Sindre Røsvik), The Netherlands (Joke Voogt and Alfons ten Brummelhuis, Bert Zwaneveld and Victor Schmidt, Jan Lepeltak), Spain (Javier Osorio and Julia Nieves,), UK (Don Passey), Ireland (Denise Leahy and Dudley Dolan,), Israel (Ben-Zion Barta and Liora Shapiro, Yaacov Katz), USA (Kevin Parker and Bill Davey), Finland (Jari Koivisto), Australia (Arthur Tatnall, William Keane) and Poland (Maciej Sysło). It is interesting to note similarities between the countries, both in what they did and when they did it. We can consider this time in terms of four periods. 


\subsection{The Punch Card Period}

In the first half of the 1970s students in many countries were writing programs using punch (or mark sense) cards run on a mini or mainframe at a local university. Their programs mostly related to mathematics, and their teachers were typically mathematics or science teachers who had done some computer programming in their university degree courses. The punch card era could be seen to have evolved from the efforts of these teachers.

This could really be seen as a 'pre-computers in schools' period. In this era the ability to make a computer do anything seemed a huge accomplishment. Those who tell of this era speak of the unbelievable patience of students waiting days to be told something like: 'syntax error in line 2'. The existence of punch card based computing did, however, provide a vehicle for convinving parents and administrators that computers were in some way relevant to schools. One should not discount the importance of public opinion on the later massive governmental and local efforts to find the resources to get computing going in schools.

\subsection{Experimentation with the Microcomputer}

By the late 1970s and early 1980s most countries were experimenting and coming to grips with what to do about the microcomputer and how it could best be used in their schools. Hardware was pre-eminent during this period, as there were few standards in common between manufacturers in hardware or application software. There was much discussion on whether it would be best to use Apple, Commodore, BBC, IBM $\mathrm{PC}$ or CP/M computers. Seymour Papert's book Mindstorms [1] was published in this periods and experimentation began in many schools with the use of Logo. (Logo was, of course, developed in the early 1970s but was then running on minicomputers not easily accessible to schools.) The statistics in the Parker and Davey chapter show that it was the accessibility of microprocessor based systems that provided the impetus to make computing a viable classroom alternative. The first classroom computers were little more use than a card punch machine as student/computer ratios were initially very poor. The champions in each school could, however, leverage their experiments to justify further purchase and that was the principal channel for widespread computing in the countries we have presented.

\subsection{Development of National Policies}

The first half of the 1980s was the time when most countries started to take computers in schools seriously: to develop national policies and curriculum guidelines and to provide support and funding to schools. This was an important time and has been discussed in detail in many chapters. It is clear that many countries had significant vision when it came to both curriculum and policy. Many countries had policy in place well in advance of the widespread use of computers and those policies seem to be broad in their vision of computer use. 


\subsection{Consolidation}

By the second half of the 1980s things had begun to settle down and there was more constructive discussion of curriculum and the most productive ways of using the computers. The number of computers in schools continued to increase rapidly.

\section{$2 \quad$ A Student View}

Several chapters described what it was like to be a school student in this period. These included: Australia (Therese Keane, Martin Chambers), South Africa (Martin Olivier), Chile (Fernando Toro) and the UK (Michael Hammond), and a number of these former students are now themselves teachers. These chapters provide a quite different perspective on this history. As many of us were past school age by this time it is good to see the other side of the story from a student perspective.

\section{Teachers' Personal Reflections}

Many of the chapters describe their author's personal teaching experiences with computers. These include a chapter by David Demant who describes his personal experiences in secondary schools in England, Canada and Australia as well as working in the Melbourne Museum. Another by Arthur Tatnall relates his personal experiences as a teacher, as an educational consultant and when working in an educational support unit in Melbourne. Alnaaz Kassam from Canada relates her journey as a teacher and her efforts to use new technologies to create inclusive curricula that were reflective of diverse societies. Other personal reflection chapters include those by: Stewart Martin, Therese Keane, Jari Koivisto, Richard Millwood, William Keane, Martin Chambers, Angela Lecomber and Michael Hammond.

\section{Teacher Education}

Most teachers both now and in the 1970s and 1980s came to their schools with a good background from 'teaching method subjects' in their own university teacher education. These teaching method subjects were designed to acquaint the potential teachers with standard approaches to teaching material relevant to their speciality. In the 1970s and 1980s this was, however, rarely the case for teachers working with computers. These teachers typically had no pre-service teacher education relating to educational uses of computers as there was none available at the time. One of the chapters in this book (by John Murnane) describes a Graduate Diploma in Computer Education course in Melbourne, Australia. Other similar courses existed elsewhere, but these were a new development. Another way that new teachers have an understanding of how to teach their material is by remembering how they were themselves taught, and their own experiences as a school student. Sometimes these experiences were positive, sometimes not but they had at least seen how someone else taught the subject 
material. This also was not the case for teachers involved with computers in the 1970s and 1980s. Most teachers at this time had to work out for themselves what best to do with computers in the classroom. Some help was provided in many cases through day or half day long professional development activities, typically provided by education department support groups, but more assistance would have been desirable.

The important issue of teacher education was mentioned in many papers from around the world. These included: UK (Stewart Martin, Don Passey, Angela Lecomber, Richard Millwood), Australia (John Murnane, Therese Keane, William Keane, Anne McDougall et al.), Norway (Sindre Røsvik), USA (Kevin Parker and Bill Davey), Spain (Javier Osorio and Julia Nieves), Poland (Maciej Sysło), The Netherlands (Joke Voogt and Alfons ten Brummelhuis, Bert Zwaneveld and Victor Schmidt, Jan Lepeltak), Israel (Ben-Zion Barta and Liora Shapiro), Ireland (Denise Leahy and Dudley Dolan) and Finland (Jari Koivisto).

\section{$5 \quad$ Curriculum Issues}

The introduction and use of Logo [1] in schools is discussed in several chapters. The chapter by Anne McDougall, John Murnane and Sandra Wills describes the development and use of Logo in Australia. They note that Logo was expressly designed as a mathematical language for use in education and was very logic-orientated. Their chapter particularly mentions how the addition of Seymour Papert's 'Turtle' made Logo far more accessible to students and teachers. Logo is also discussed in chapters by Martin Chambers and Michael Hammond.

Another major curriculum issue at the time was whether the main emphasis should be to 'teach about computing', to use computers in many subject areas 'across the curriculum', or both. This issue arose in a number of chapters. In many countries teaching about computing - often called computer studies or computer science, was very popular during the first half of the 1980 s, but after this time began to lose its place as teachers were keener to make use of the computer just as a tool in other subject areas. Schools in many countries spent much of their time in activities like teaching word processing or the use of a spreadsheet. Of course this need not have been an either/or situation, but in a number of countries it was with the result that computer studies lost out. It is interesting to note recent developments in which a number of countries are again stressing the importance of computer studies (or computer science or whatever name it is given).

\section{$6 \quad$ Other Issues}

A number of chapters also deal with other important issues related to computers in education. Developments in the use of computers in school management are described by Rory Butler and Adrie Visscher, and also by Richard Taylor. Pedagogy, in relation to the use of computers in schools, is discussed by Stewart Martin, Don Passey, Eva Dakich and Angela Lecomber. Richard Taylor writes on a blurring of boundaries between home and school computer use, and also within schools in the way that 
teaching and learning are carried out. Eva Dakich describes the dominant discourses, epistemological frameworks and theories of learning that have influenced the deployment of new technologies and their integration into learning and teaching.

\section{But Has Education Really Changed for the Better as a Result?}

In the 1970s and 1980s many of us who were involved in the introduction and use of computers in schools believed that we could fundamentally change education for the better. We believed that in using computers, students could achieve many new things such as making use of science simulations, creating their own applications in different subject areas, developing thinking through the design of algorithms and writing of computer programs, expressing ideas and experimenting through play with things like Logo and through learning how to use sophisticated graphics and audio applications. Senior secondary school students could also learn about and use computers as preparation for jobs in science, business and industry. In many cases our own motivations to get into this area related to our excitement and sense of achievement in making a computer do something that we had determined: in programming.

In an article in The Australian newspaper in 1990, however, Peter Juliff [2] argued that in using the computer only as a tool, "We have succumbed to the terminal atrophy of imagination". He goes on to say that: "In the process of moving the mystique of the '60s to the blasé reality of the '90s, we have lost sight of the magic and the wonder." Juliff suggests that schools need to be more adventurous and creative in their use of computers. He notes that: "Often they are only used as labour-saving devices in the same way as dishwashers and microwave ovens."

This sentiment seems not to have been restricted just to Australia, as many authors from around the world have expressed similar sentiments. It could be said that in the early $21^{\text {st }}$ century computers in schools are used largely for typing (word processing), access to an encyclopaedia (the Internet) and communication (email). Is this what we envisaged at the beginning?

In the 1960s in the USA and in Australia (and in many other countries around the world) the physics syllabus in the last two years of secondary schools was given a significant boost by the introduction of PSSC Physics [3]. The Physical Science Study Committee (PSSC) in the USA set out to integrate experiment and theory and to introduce principles through the use of lost cost, but interesting and accessible equipment. The idea was that the students could get a good understanding of what was going on, rather than just getting lost in the use of complex equipment or being taught pure theory.

If we compare this with approaches to the use of computers in education, many current computer applications just teach the student how to use tools; how to use 'complex pieces of equipment' such as Microsoft Word, Microsoft Excel, Google, Wikipedia, Facebook etc. rather than to integrate practice with theory. By contrast, approaches involving algorithmic design and programming, as well as the use of tools, could bear some relationship to the PSSC approach. Papert also had some ideas 
on this [4]. A commentary from 1993 foretells of a fundamental difficulty in attaining the ideals of Papert:

"the seemingly marginal use of computers and telecommunications in schools and classrooms is due less to inadequate funds, unprepared teachers, and indifferent administrators than to dominant cultural beliefs about what teaching, learning, and proper knowledge are and how schools are organized for instruction." [5:15]

Has the use of computers in education changed education in the way we thought it might in the 1980s? Has it resulted in a significant difference and an improvement, or just a different way of doing the same old things? Have we lost sight of the magic and the wonder?

\section{References}

1. Papert, S.: Mindstorms - Children, Computers and Powerful Ideas. Harvester Press, Sussex (1980)

2. McIntosh, T.: Schools are Trapped in 'Typewriter' Mentality, in The Australian, Melbourne, p. 35 (1990)

3. Chiaverina, C.: Teaching PSSC Physics: A Remembrance of Things Past, in PSSC 50 Years Later. American Association of Physics Teachers (2006)

4. Papert, S.: The Connected Family: Bridging the Digital Generation Gap. Longstreet Press, Atlanta (1996)

5. Cuban, L.: Computers Meet Classroom: Classroom Wins. The Teachers College Record 95, $185-210$ 